\title{
IODOACETATE POISONING OF THE RAT RETINA* I. PRODUCTION OF RETINAL DEGENERATION
}

\author{
BY \\ CLIVE GRAYMORE $\dagger$ AND KATHARINE TANSLEY $\ddagger$ \\ Institute of Ophthalmology, University of London
}

IT is now well established that retinal degeneration can be produced in several species of laboratory animals by intravenous injection of sodium iodoacetate (Schubert and Bornschein, 1951; Noell, 1952; Berardinis, 1953; Karli, 1954; Rabinovitch, Mota, and Yoneda, 1954; Babel and Ziv, 1956). Thus, Noell (1952) described a destruction of the visual cells in rabbits, cats, and monkeys after repeated doses, and drew attention to the close similarity between the experimental condition and retinitis pigmentosa in man (Noell, 1953). Most workers have used rabbits for these studies, but Rabinovitch and others (1954) recorded the same result in chickens. So far the rat has been found to be an unsatisfactory animal for such experiments; Rabinovitch and his co-workers (1954) failed to obtain retinal degeneration in this species after repeated sub-lethal doses.

Noell (1952) has remarked on the difficulty of finding a single sub-lethal dose which would produce histologically recognizable damage to the retina. Most of his studies in rabbits involved the use of repeated doses of 15 to 20 $\mathrm{mg} . / \mathrm{kg}$. body weight $(12 \mathrm{mg}$. $/ \mathrm{kg}$. in the cat). In this laboratory, however, it has been found possible to produce histological damage in the rabbit by giving a single injection of $40 \mathrm{mg} . / \mathrm{kg}$. In order to achieve this without killing the animal it was necessary to administer the dose in at least $10 \mathrm{ml}$. saline over a period of about 20 minutes (Tansley, 1955).

The present observations arose out of attempts to produce retinal degeneration in the rat for metabolic studies. We also failed to achieve this in the rat with a single sub-lethal dose and therefore tried other procedures.

\section{Material and Methods}

Injection of Animals.-Albino rats of either sex were used, and were maintained on the standard diet used in this laboratory. They were aged 3 to 4 months and their weights fell within the range of 150 to $200 \mathrm{~g}$. Intravenous injections were given via one of the tail veins.

Solutions.-The sodium iodoacetate was recrystallized from a sample obtained from British Drug Houses Ltd., and was carefully neutralized with sodium hydroxide. A stock solution was freshly prepared for each experiment, and before

* Received for publication April 10, 1958.

+ Department of Pathology.

$\ddagger$ Wernher Research Fellow, Medical Research Council.

12 
each injection the required dose was made up to $1 \mathrm{ml}$. with saline. L-malic acid, obtained from Light and Co. Ltd., was neutralized with sodium hydroxide and diluted with saline before use. Where iodoacetate and malate were given simultaneously, the two stock solutions were mixed in the desired proportions and made up to $1 \mathrm{ml}$. with saline as before. Sodium pyruvate was obtained from Roche Products Ltd., dissolved in distilled water, and neutralized before use. Control animals received $1 \mathrm{ml}$. saline only.

Histology.-Animals which survived the injections were killed 7 or 8 days later by intravital fixation under Nembutal anaesthesia. The upper part of the body only was fixed (the descending aorta being ligatured) with either Kolmer's or Zenker's fluid. The anterior part of each eye was cut away during dehydration and the posterior part embedded in paraffin. Serial sections were cut at $6 \mu$. Five staining methods were used:

(1) Haematoxylin and eosin.

(2) Iron haematoxylin and aniline blue-orange $G$ mixture.

(3) Mallory's phosphotungstic acid haematoxylin.

(4) Azan method.

(5) Feulgen's technique.

\section{Results}

\section{Single Injection of Iodoacetate}

There was some variation in the response of the animals which we attributed partly to individual variation and partly to the fact that the lethal dose is so critical that small differences in the purity of the iodocetate will affect the result. For this reason the lethal dose was established afresh for each experiment. A general analysis of a large number of experiments is given in Table I, which shows that a dose of $40 \mathrm{mg} . / \mathrm{kg}$. body weight is usually tolerated and that the mortality rises as the dose is increased, there being no survivors at $70 \mathrm{mg} . / \mathrm{kg}$. Retinae from approximately half the surviving animals were examined histologically. In no case was there any evidence of degeneration.

\section{TABLE I}

EFFECT OF THE SIZE OF A SINGLE DOSE OF IODOACETATE ON SURVIVAL RATE

\begin{tabular}{c|c|c|c}
\hline $\begin{array}{c}\text { Dose } \\
\text { (mg./kg.) }\end{array}$ & $\begin{array}{c}\text { No. of } \\
\text { Animals }\end{array}$ & Deaths & Survivals \\
\hline 40 & 8 & 1 & 7 \\
\hline 50 & 6 & 3 & 3 \\
\hline 60 & 27 & 19 & 8 \\
\hline 70 & 6 & 6 & 0 \\
\hline
\end{tabular}


These results indicate that the rat can tolerate larger doses of iodoacetate than other laboratory animals so far examined. We believe that even bigger doses could be used if it were practicable to give them in more dilute solutions over a longer period. Under such conditions it may well be that retinal degeneration could be produced by a single dose.

\section{Injection of Iodoacetate and Malate}

Recent evidence indicates that the metabolism of the visual cells may not be identical with that of the rest of the retina (Noell, 1952; Lowry, Roberts, and Lewis, 1956), and Noell (1951) has suggested that in the visual cells glycolysis plays a major part in energy production and that this may account for their specific sensitivity to iodoacetate. Iodoacetate is known to be a general-SH enzyme poison having a particularly marked effect on glycolysis. It occurred to us, therefore, that it might be possible to protect the life of an experimental animal by providing it with some suitable energy-producing intermediate which could bypass the iodoacetate block without affecting glycolysis. We know of no evidence that malic dehydrogenase is inhibited by iodoacetate and sodium malate was therefore chosen. The procedure was to give $50 \mathrm{mg}$. malate in $1 \mathrm{ml}$. saline followed immediately by a further injection of $50 \mathrm{mg}$. malate together with the chosen dose of iodoacetate. Control animals were treated with saline and iodoacetate on the same day using the same iodoacetate solution.

Table II shows that sodium malate exerts a protective action against a dose of $60 \mathrm{mg} . / \mathrm{kg}$. iodoacetate, but has little effect if the iodoacetate dose is raised to $70 \mathrm{mg} . / \mathrm{kg}$. We did observe, however, that, whereas the unprotected animals in this last group frequently died within an hour of the injection, those given malate survived considerably longer, usually being found dead

TABLE II

EFFECT OF MALATE WITH IODOACETATE ON SURVIVAL RATE

\begin{tabular}{c|c|c|c}
\hline $\begin{array}{c}\text { Dose } \\
(\mathrm{mg} . / \mathrm{kg} .)\end{array}$ & $\begin{array}{c}\text { No. of } \\
\text { Animals }\end{array}$ & Deaths & Survivals \\
\hline $\begin{array}{c}60 \\
\text { Iodoacetate }+ \text { Saline }\end{array}$ & 10 & 8 & 2 \\
\hline $\begin{array}{c}60 \\
\text { Iodoacetate }+ \text { Malate }\end{array}$ & 6 & 0 & 6 \\
\hline $\begin{array}{c}70 \\
\text { Iodoacetate }+ \text { Saline }\end{array}$ & 6 & 6 & 0 \\
\hline 70 & 10 & 8 & 2 \\
\hline Iodoacetate + Malate & &
\end{tabular}


the next morning. In both the protected animals which survived a dose of $70 \mathrm{mg} . / \mathrm{kg}$. iodoacetate, slight retinal degeneration was present.

\section{Divided Dose of Iodoacetate}

Noell (1952), in his work on iodoacetate-induced retinal degeneration, has found that a given dose is more effective when divided, presumably because the effect is dependent on the maintenance of a critical concentration for a sufficient length of time. We decided to investigate, therefore, the effect of a dose of $60 \mathrm{mg}$. $/ \mathrm{kg}$. given in two equal doses separated by approximately 4 hours. Out of a total of 25 animals treated in this manner, there were fourteen survivals representing a 56 per cent. survival rate. This figure is substantially higher than the rate for the same dose given all at once $(29.6$ per cent. calculated from Table I). Most of the animals which survived the divided dose showed moderate retinal degeneration (see below).

\section{Divided Dose with Malate}

The results of three experiments comparing the effect of divided doses of iodoacetate with and without malate are shown in Table III. $50 \mathrm{mg}$. malate were given immediately before and together with each injection of iodoacetate. It should be noted that the survival rate of those animals treated with $60 \mathrm{mg} . / \mathrm{kg}$. iodoacetate given in two doses was lower than that recorded in the last section. We have already remarked on the variability of the lethal dose of iodoacetate, and these results emphasize the importance of satisfactorily controlling each separate series of experiments, particularly when different solutions of iodoacetate are used. Table III shows again that there is a better survival rate when malate is given with the iodoacetate, although the effect is not quite so marked as when single doses are used.

TABLE III

EFFECT OF MALATE WITH A DIVIDED DOSE OF IODOACETATE ON SURVIVAL RATE

\begin{tabular}{c|c|c|c}
\hline $\begin{array}{c}\text { Dose } \\
(\mathrm{mg} . / \mathrm{kg} .)\end{array}$ & $\begin{array}{c}\text { No. of } \\
\text { Animals }\end{array}$ & Deaths & Survivals \\
\hline $\begin{array}{c}60 \\
\text { Iodoacetate }+ \text { Saline }\end{array}$ & 14 & 10 & 4 \\
\hline $\begin{array}{c}60 \\
\text { Iodoacetate }+ \text { Malate }\end{array}$ & 10 & 5 & 5 \\
\hline $\begin{array}{c}70 \\
\text { Iodoacetate }+ \text { Saline }\end{array}$ & 9 & 9 & 0 \\
\hline Iodoacetate + Malate & 9 & 6 & 3 \\
\hline
\end{tabular}


It is worth adding, perhaps, that, of those animals which died after receiving $70 \mathrm{mg}$. $/ \mathrm{kg}$., six of the nine which were unprotected by malate died immediately, whereas five of the six protected animals survived until the following night. This indicates that the effect of malate may be rather greater than would appear from the Table.

\section{Effect of Other Intermediates}

A few experiments were done using two other Krebs cycle intermediates, sodium glutamate and sodium pyruvate. The former appeared to have little or no protective effect and experiments with this substance were not continued. Sodium pyruvate, on the other hand, showed a definite protective action. Four of the six treated animals survived, and the two deaths did not occur until the second and third days after the injection. Of the seven control animals only two survived and both appeared very ill a week later. These two survivors had lost almost one third of their body weight during this period, while the pyruvate survivors had lost no weight at all.

\section{Retinal Degeneration}

Schubert and Bornschein (1951) and Noell (1952) have described the histological appearance of the rabbit retina 3 weeks after repeated injections of sub-lethal doses of iodoacetate. They found that the retinae were devoid of almost all visual cells except in the region of the ora serrata and in a small area around the optic nerve. In the cat and monkey, Noell (1952) found that the rods and their nuclei were destroyed by doses which left the cones unaffected. The rat retina is like that of the rabbit in that it contains very few cones, the vast majority of the visual cells being rods (Fig. 1). Where retinal

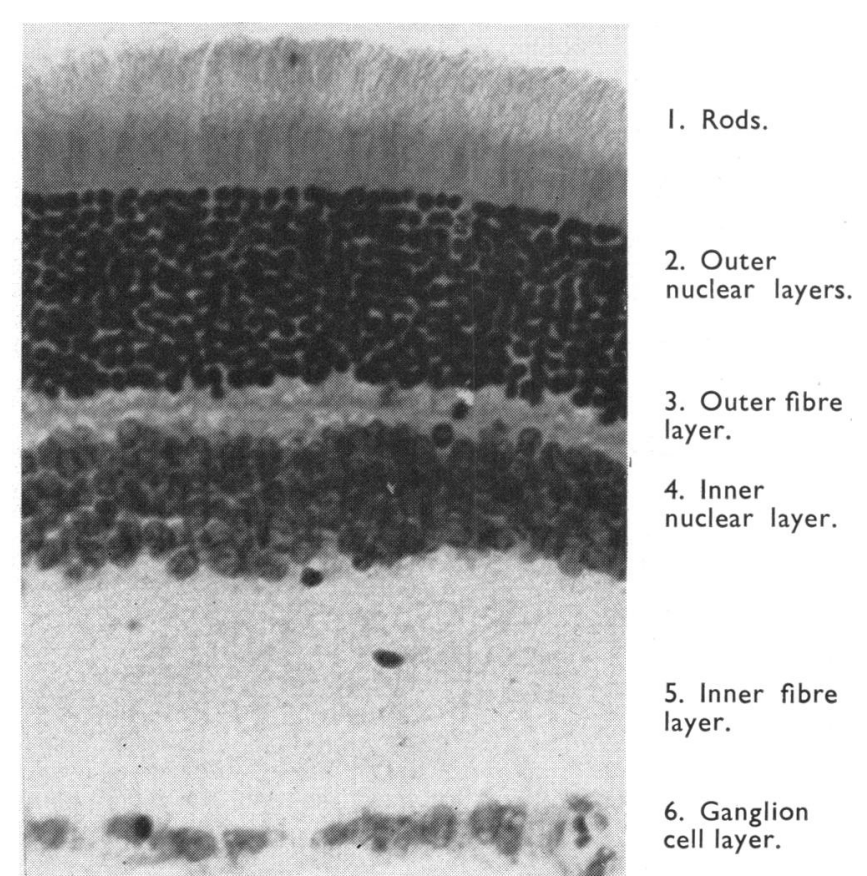

FIG. 1.-Section through normal rat retina. Bouin; haematoxylin and eosin. $\times 325$. 
degeneration was produced in our experiments it always took the form of a destruction of a greater or less proportion of the rods and their nuclei.

In most of his animals Noell did not carry out a histological examination of the retina until the electroretinogram had been irreversibly abolished and this condition is usually associated with an almost complete loss of rods. In a few rabbits, however, there were variations in the amount of visual cell loss and in those less affected the worst damage was found in the central retina, ventral to the optic nerve entrance, in a small area about half-way between the nerve and the ora serrata. In general the retinal degeneration in our rats was much less severe than that described by Noell (1952) in rabbits, but the distribution of the damage was very similar. Thus, even in our worst affected eyes, there was a ring of normal retina just behind the ora serrata, and usually, but not always, another round the optic nerve. Where the retinae were not so badly affected, the worst damage was found in the central retina ventral to the nerve.

In the least affected retinae ( + in Table IV, opposite), some normal visual cell nuclei were present throughout, but in a rather restricted central area the outer nuclear layer was reduced from ten to twelve, to only five to seven cells thick. In those considered to be moderately affected $(++$ in Table IV and Fig. 2), the outer nuclear layer might be much reduced over perhaps one-third to half the retina, with small areas where it was only one cell thick or entirely destroyed.

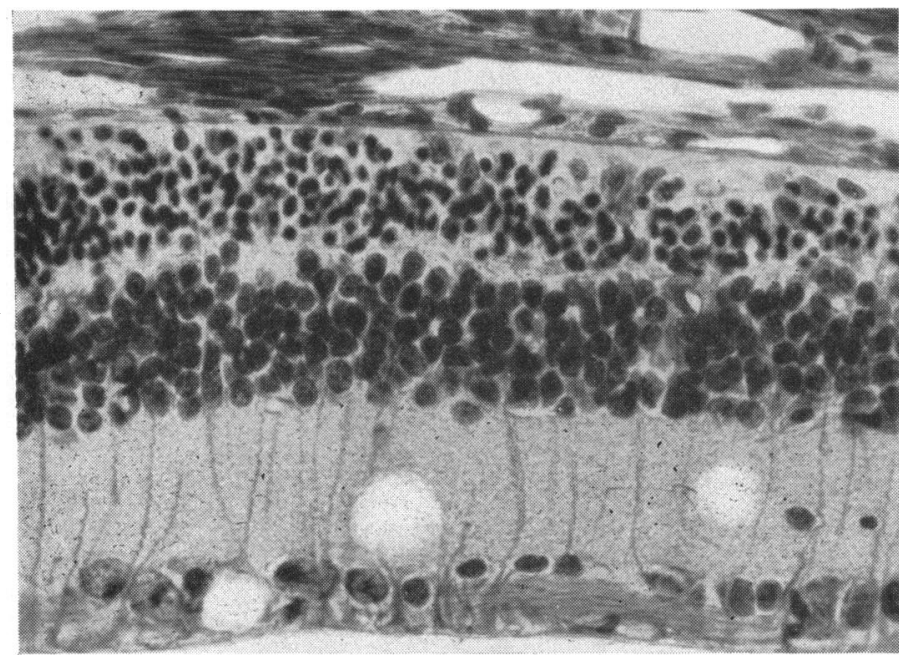

2. Outer nuclear layers.

4. Inner nuclear layer.

Fig. 2.-Rat retina 7 days after $60 \mathrm{mg} . / \mathrm{kg}$. iodoacetate given as a divided dose. The rods and outer nuclear layer have been damaged but not completely destroyed. Kolmer; Mallory's phosphotungstic acid haematoxylin. $\times 387$.

In the most affected retinae $(++++$ in Table IV, opposite, and Fig. 3, overleaf) the outer nuclear layer might be completely destroyed over as much as three-quarters of the retina. 
Table IV shows that, in general, there was only moderate damage to the retina when iodoacetate was given alone as a divided dose. The addition of malate produced a much more severe retinal degeneration. A similar effect was observed in a rabbit experiment. In this connexion it is interesting that, although pyruvate gave as much, if not more, protection against iodoacetate as malate, it certainly did not increase the amount of retinal degeneration.

\section{Discussion}

As already pointed out, our reason for choosing sodium malate as a possible protective agent was based on the assumption that its conversion to oxaloacetate would not be inhibited by sodium iodoacetate. It should, therefore, provide a source of energy which might protect the life of the animal. If the visual cells are primarily dependent on glycolysis, a respiratory substrate such as malate would not be expected to help them. In this

TABLE IV

RETINAL DEGENERATION PRODUCED BY DIVIDED DOSE OF IODOACETATE

\begin{tabular}{|c|c|c|c|c|c|}
\hline \multicolumn{3}{|c|}{ Without Malate } & \multicolumn{3}{|c|}{ With Malate } \\
\hline Rat No. & $\begin{array}{c}\text { Dose } \\
\text { (mg./kg.) }\end{array}$ & Degeneration & Rat No. & $\begin{array}{c}\text { Dose } \\
\text { (mg./kg.) }\end{array}$ & Degeneration \\
\hline 100 & 50 & + & 155 & 60 & ++++ \\
\hline 99 & 55 & + & 157 & 60 & ++++ \\
\hline 101 & 55 & ++ & 158 & 60 & ++++ \\
\hline 102 & 55 & ++ & 159 & 60 & +++ \\
\hline 16 & 60 & - & 204 & 60 & ++++ \\
\hline 19 & 60 & + & 175 & 70 & +++ \\
\hline 20 & 60 & ++ & 176 & 70 & ++++ \\
\hline 21 & 60 & ++ & \multirow{11}{*}{\multicolumn{3}{|c|}{$\begin{array}{l}\text { way we hoped to produce sufficient } \\
\text { retinal degeneration for metabolic } \\
\text { studies without killing the animal. } \\
\text { On the other hand, if the visual cel } \\
\text { metabolism is not peculiar, the } \\
\text { effect of malate on the survival of } \\
\text { poisoned animals should be reflect- } \\
\text { ed in the retina as a decreased de } \\
\text { gree of degeneration. The results } \\
\text { show that malate did indeed exert a } \\
\text { significant protective action on the } \\
\text { animal as a whole, but did no } \\
\text { prevent retinal degeneration. On }\end{array}$}} \\
\hline 103 & 60 & ++ & & & \\
\hline 104 & 60 & ++ & & & \\
\hline 109 & 60 & ++ & & & \\
\hline 111 & 60 & ++ & & & \\
\hline 118 & 60 & ++ & & & \\
\hline 148 & 60 & ++ & & & \\
\hline 149 & 60 & ++ & & & \\
\hline 161 & 60 & +++ & & & \\
\hline 162 & 60 & + & & & \\
\hline 119 & 63 & ++ & & & \\
\hline
\end{tabular}



4. Inner nuclear
layer.

5. Inner fibre layer.

6. Ganglion cell layer.

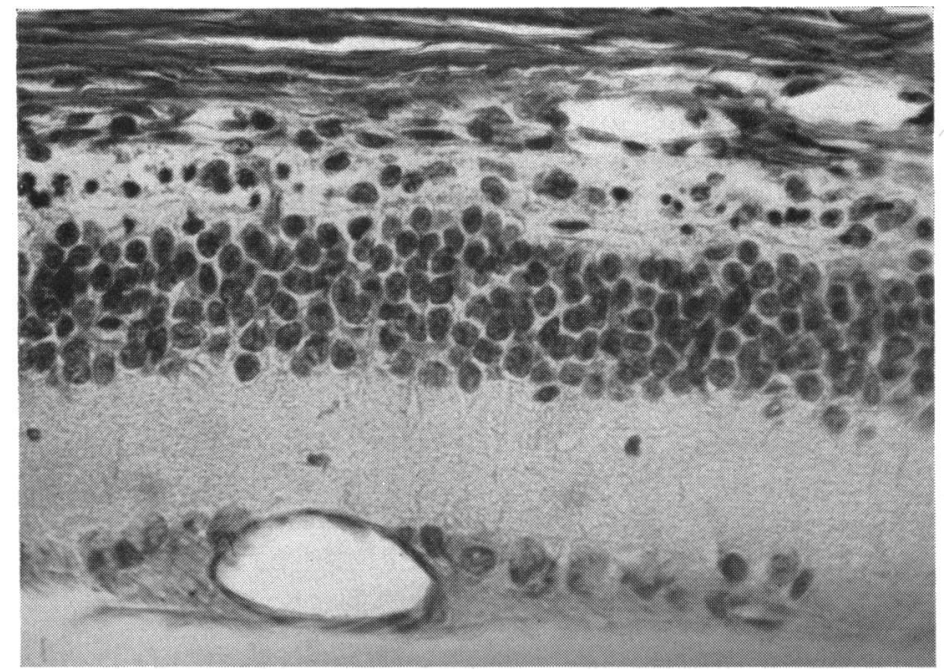

FIG. 3.-Rat retina 7 days after $60 \mathrm{mg} . / \mathrm{kg}$. iodoacetate given as a divided dose together with malate. The rods and outer nuclear layer have virtually disappeared. Kolmer; Mallory's phosphotungstic acid haematoxylin. $\times 387$.

the contrary the effect of malate was to increase the damage to the visual cells. This fact is hard to explain on our original simple assumption.

Malate by itself does not produce any histological damage to the retina. It was suggested to us that this substance might exert its effect by its conversion to pyruvate rather than to oxaloacetate, for it has been thought that the nervous damage associated with thiamine deficiency might in part be due to the high levels of blood pyruvate found in this condition (see Mcllwain, 1955). However, our results indicate that the malate effect on the retina is not due to an accumulation of pyruvate, for injection of this latter substance did not increase the damage due to iodoacetate.

Another possibility is that the oxidative decarboxylation of malate to pyruvate would deplete the available oxidized triphosphopyridine nucleotide (TPN) which may be required for the operation of the Warburg-Dickens shunt. It is known that in some biological systems iodoacetate does not completely inhibit the utilization of glucose, and this is attributed in part to the operation of this alternative breakdown pathway involving the TPNdependent conversion of glucose-6-phosphate to 6-phosphogluconic acid. If part of the energy production of the retina can be accounted for by this iodoacetate-insensitive route, interference with the mechanism by depletion of TPN may further decrease the energy production of the iodoacetate poisoned cells and enhance the resultant damage.

Although the oxidative decarboxylation of pyruvate involves - $\mathrm{SH}$ groups, it must be assumed that a sub-lethal dose of iodoacetate is insufficient 
entirely to prevent the utilization of this substance; hence its protective action on the life of the animal.

It is true that the protective action of malate as used in these experiments was not very great. This is understandable, since owing to its relative insolubility we were unable to give larger doses. It has, however, proved extremely useful by virtue not only of its protective effect on the animal but also of its action in increasing the iodoacetate destruction of visual cells. By using divided doses of iodoacetate together with malate we have been able to produce retinae in which a large proportion of the visual cells has been destroyed. These provide excellent material for studying the differential metabolism of the retina.

\section{Summary}

(1) Single sub-lethal doses of sodium iodoacetate did not produce retinal degeneration.

(2) Moderate visual cell damage was produced by giving two doses of $30 \mathrm{mg} . / \mathrm{kg}$. body weight separated by an interval of 4 hours.

(3) Both sodium malate and sodium pyruvate exerted a protective action on animals treated with iodoacetate.

(4) Sodium malate enhances the degenerative effect of iodoacetate.

Our grateful thanks are due to Dr. Margaret Kerly for helpful discussion and to Professor Norman Ashton for reading this manuscript, and we also acknowledge the technical assistance of Mrs. D. A. Cairns. We would like to thank the Medical Research Council for a grant towards the expenses of this investigation.

\section{REFERENCES}

BABEL, J., and Ziv, B. (1956). Ophthalmologica (Basel), 132, 65.

BERARDINIS, E. DE (1953). Rass. ital. Ottal., 22, 345.

Karli, P. (1954). C. R. Ass. Anat., 78, 244.

LOWRY, O. H., RoberTS, N. R., and LeWIS, C. (1956). J. biol. Chem., 220, 879.

McIllwaIN, H. (1955). "Biochemistry and the Central Nervous System", p. 133. Churchill, London.

Noell, W. K. (1951). J. cell. comp. Physiol., 37, 283.

(1952). Ibid., 40, 25.

(1953). Amer.J. Ophthal., 36, 103.

Rabinovitch, M., Mota, I., and Yoneda, S. (1954). Experientia (Basel), 10, 187.

SCHUBERT, G., and BORNSCHEIN, H. (1951). Ibid., 7, 461.

TANSLEY, K. (1955). Unpublished observations. 